\title{
MYOC Gene Sequencing Analysis in Primary Open-Angle Glaucoma Patients from the Centre Region of Portugal
}

\author{
Análise por Sequenciação do Gene MYOC em Doentes \\ com Glaucoma Primário de Ângulo Aberto da Região \\ Centro de Portugal
}

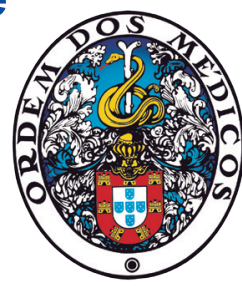

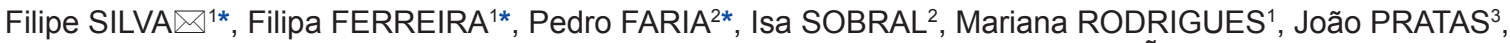
João Filipe SILVA ${ }^{2}$, Manuela GRAZINA', ${ }^{3,4}$, José MOURA PEREIRA ${ }^{2}$, Henrique GIRÃO'1, Paulo PEREIRA'

Acta Med Port 2021 Sep;34(9):586-591 - https://doi.org/10.20344/amp.14922

\section{ABSTRACT}

Introduction: Primary open-angle glaucoma is the most frequent subtype of glaucoma. Relatives of primary open-angle glaucoma patients have an increased risk of developing the disease, suggesting a genetic predisposition to the disease. MYOC was the first primary open-angle glaucoma-causing gene identified. This study aimed to identify sequence variations in the MYOC gene that may be responsible for the phenotype in a group of primary open-angle glaucoma patients from the Centre Region of Portugal.

Material and Methods: The three coding exons and the proximal splicing junctions of the MYOC gene were studied using a PCRsequencing approach in a group of 99 primary open-angle glaucoma patients.

Results: The sequencing analysis enabled the identification of 20 variants, including four in the promoter region, seven in the introns and nine in exons one and three, of which four were missense variants.

Discussion: Initially, all four missense sequence variations identified were considered candidates to glaucoma causing disease mutations. However, after literature review, only variant c.1334C>T (Ala445Val) remained as likely responsible for mild late-onset normal tension glaucoma.

Conclusion: This is the first study performed in a group of primary open-angle glaucoma patients from the Centre Region of Portugal, contributing to the identification of one genetic variant in the MYOC gene and reinforcing the hypothesis that normal tension glaucoma could be also due to MYOC gene mutations.

Keywords: Genetics; Glaucoma/diagnosis; Low Tension Glaucoma; Mutation, Missense

\section{RESUMO}

Introdução: O glaucoma primário de ângulo-aberto é o subtipo mais frequente de glaucoma. Os familiares de doentes com glaucoma primário de ângulo-aberto têm um risco maior de desenvolverem a doença, o que sugere uma predisposição genética para a doença. MYOC foi o primeiro gene causador de glaucoma primário de ângulo-aberto a ser identificado. Este estudo pretendeu identificar variações de sequência no gene $M Y O C$ que possam ser responsáveis pelo fenótipo num grupo de doentes com glaucoma primário de ângulo-aberto da Região Centro de Portugal.

Material e Métodos: Os três exões codificantes e as regiões adjacentes do gene MYOC foram estudados utilizando o método de PCR-sequenciação num grupo de 99 doentes com glaucoma primário de ângulo aberto.

Resultados: A análise de sequenciação permitiu identificar 20 variantes, incluindo quatro na região promotora, sete nos intrões e nove nos exões um e três, das quais quatro eram variantes missense.

Discussão: Inicialmente, todas as quatro variações de sequência missense identificadas foram consideradas candidatas a mutações causadoras de glaucoma. No entanto, após análise da literatura, somente a variante c.1334C>T (Ala445Val) permaneceu como provável responsável pelo glaucoma de pressão normal de início tardio.

Conclusão: Este é o primeiro estudo realizado num grupo de doentes com glaucoma primário de ângulo aberto da Região Centro de Portugal, contribuindo para a identificação de uma variante genética no gene $M Y O C$ e reforçando a hipótese de que o glaucoma de pressão normal também poderá ser causado por mutações no gene MYOC.

Palavras-chave: Genética; Glaucoma/diagnóstico; Glaucoma de Baixa Pressão; Mutação Missense

\section{INTRODUCTION}

Glaucoma is a group of optic neuropathies essentially characterized by a progressive degeneration of retinal ganglion cells (RGCs) and their axons, leading to excavation in the optic nerve head and, consequently, characteristic, progressive and irreversible visual field defects. ${ }^{1}$ At the beginning, the peripheral vision loss may not interfere with the daily routine and remains undetected. ${ }^{2}$ Therefore, until an advanced stage of the disease is reached, which usually consists on central vision loss, most patients are unaware that they have the disease and, consequently, remain undiagnosed and untreated. ${ }^{3}$

This ocular disease is the second leading cause of blindness ${ }^{4}$ and the leading cause of irreversible blindness in the world, affecting 67 million people, of which $85 \%$ - 90\%

\footnotetext{
* These authors contributed equally to this study.

1. Institute for Clinical and Biomedical Research (iCBR). Faculty of Medicine. University of Coimbra. Coimbra. Portugal.

2. Ophthalmology Department. Centro Hospitalar e Universitário de Coimbra. Coimbra. Portugal.

3. Laboratory of Mitochondrial BioMedicine and Theranostics. Center for Neurosciences and Cell Biology. Coimbra. Portugal.

4. Institute of Biochemistry. Faculty of Medicine. University of Coimbra. Coimbra. Portugal.

$\square$ Autor correspondente: Filipe Silva. filipe.m.pereira.silva@gmail.com

Recebido: 16 de setembro de 2020 - Aceite: 03 de dezembro de 2020 - First published: 16 de março de 2021 - Online issue published: 01 de setembro de 2021 Copyright $\odot$ Ordem dos Médicos 2021
} 
have primary open-angle glaucoma (POAG) in developed countries. $^{5-6}$ It is estimated that the number of people with glaucoma in the world will increase to 76 million in 2020 and to 111.8 million in 2040, from which 52.7 million and 79.8 million, respectively, will be POAG patients. ${ }^{7}$

Although the pathogenesis of POAG has not been fully elucidated, there are known risk factors for the disease including elevated intraocular pressure (IOP), age, ethnicity, a positive family history, pseudoexfoliation, central corneal thickness, myopia and ocular perfusion pressure. ${ }^{4,6}$ And even though elevated IOP is a risk factor for POAG, it is not a necessary feature for diagnosis since an important subtype of POAG, known as normal tension glaucoma (NTG), occurs at low to normal IOP levels. ${ }^{6}$ NTG accounts for approximately $20 \%-50 \%$ of all POAG cases. ${ }^{8}$

There is little doubt that a positive family history increases the risk of developing glaucoma. Relatives of POAG patients have been shown to have an eight-fold increase in the disease risk, ${ }^{4,6}$ exhibiting an autosomal dominant heredity. ${ }^{9}$ MYOC, a gene composed by three exons and encoding a protein with 504 amino acids, ${ }^{10}$ was the first POAG-causing gene identified ${ }^{11}$ and mutations in this gene are responsible for approximately $2 \%$ to $4 \%$ of the cases. ${ }^{12}$ Prior to the identification of this gene, Sunden et al mapped the GLC1A locus comprising an interval in the long arm of chromosome 1 (1q21-q31), that was associated with juvenile open-angle glaucoma (JOAG), a subtype of POAG with onset earlier than 35 years old (yo) and very high IOP. ${ }^{13}$ Afterwards, this region was limited to chromosome 1q23 q25. The defective gene in this locus was finally identified as TIGR (Trabecular meshwork-Inducible Glucocorticoid Response). ${ }^{11}$ In the meantime, Japanese researchers mapped this gene by FISH within the chromosome 1q23 - 1q24 region, and due to its homologous regions with myosin, TIGR was named MYOC. ${ }^{14}$

The myocilin protein is ubiquitously expressed in normal tissues and organs, ${ }^{15}$ widely expressed in ocular tissues and highly expressed in the trabecular meshwork (TM), where it plays an important role in the regulation of IOP. ${ }^{16-18}$ Despite a number of studies over a 20 year period since its discovery in 1997, the physiological functions and biological activities of myocilin in the TM remain poorly understood. Aggregation of aberrant mutant myocilins is closely associated with glaucoma pathogenesis. The aggregation of misfolded/wild-type myocilins in the endoplasmic reticulum (ER) may be harmful for TM cells and lead to apoptosis. ${ }^{18}$ Previous results have suggested that the TM is several times thicker in patients with glaucoma harboring mutations compared with that in patients without myocilin mutations. Therefore, myocilin mutations appear to be involved in the morphological changes in the TM, which lead to cell apoptosis. $^{19}$

The present study aimed to identify sequence variations in the MYOC gene that may be responsible for the phenotype in a group of POAG patients from the Centre Region of Portugal.

\section{MATERIAL AND METHODS}

\section{Human subjects}

A group of 99 Portuguese Caucasian POAG patients from the Centre Region of Portugal, consisting of 52 males and 47 females with an average age of 71.2 yo and ranging from 42 to 88 yo, and an average age at diagnosis of 61.7 yo and ranging from 23 to 82 yo, was recruited to this study and a clinical characterization was performed at the Ophthalmology Department of the Centro Hospitalar e Universitário de Coimbra. All patients underwent a detailed ophthalmologic examination to ensure the diagnosis of POAG including: 1) exclusion of secondary causes, 2) open drainage angles on gonioscopy (Shaffer's grading III-IV), 3) presence of typical glaucomatous optic disc damage (excavation) and 4) visual field defects detected by automated perimetry (with Humphrey's perimeter). The IOP was also evaluated since ocular tension enables the distinction of POAG subtypes. Accordingly, glaucoma patients with IOP equal or below $21 \mathrm{mmHg}$ are diagnosed as NTG. ${ }^{4}$ For the present study, 26 patients with high IOP and 73 with IOP equal or below $21 \mathrm{mmHg}$ (NTG) were randomly recruited.

This study was approved by the Ethics Committee of the Faculty of Medicine, University of Coimbra, following the tenets of the Declaration of Helsinki 2013 and a written consent for genetic testing was obtained from adult probands.

\section{Sequence variations identification}

The DNA was extracted from the peripheral blood of POAG patients using a standard phenol-chloroform method followed by ethanol precipitation. ${ }^{20}$

Individual exons and adjacent regions of the MYOC gene were amplified by polymerase chain reaction (PCR) using primers designed with Primer3 software (http://bioinfo.ut.ee/ primer3-0.4.0/primer3/). The primers nucleotide sequence will be made available upon request to the corresponding author. The PCR reactions were performed using $50 \mathrm{ng}$ of genomic DNA mixed with the following reagents: 1X Taq Buffer 10X [with $\left(\mathrm{NH}_{4}\right)_{2} \mathrm{SO}_{4}$ ] (Fermentas), $0.2 \mu \mathrm{M}$ of forward and reverse primers (Sigma-Aldrich), $1.5 \mathrm{mM} \mathrm{MgCl}_{2}$ (Fermentas), 0.2 mM dNTPs (5PRIME), $1 U$ Taq Polymerase (Fermentas) and RNAse/DNase free Water (AccuGENE) to a final volume of $10 \mu \mathrm{l}$. The reaction mixtures were subjected to a specific PCR program with an initial denaturation step of five minutes (min) at $95^{\circ} \mathrm{C}$ followed by 35 cycles, each with denaturation at $95^{\circ} \mathrm{C}$ for 30 seconds (sec), annealing at $59^{\circ} \mathrm{C}-63^{\circ} \mathrm{C}$ for $30 \mathrm{sec}$, and extension for one min at $72^{\circ} \mathrm{C}$, with a final elongation step of $10 \mathrm{~min}$ at $72^{\circ} \mathrm{C}$.

PCR products underwent an electrophoresis on an agarose gel containing $1 \%$ agarose SeaKem LE (Lonza) and $1 \%$ ethidium bromide (Acros/Fisher bioreagents) in $1 \mathrm{X}$ Tris Borate EDTA (TBE) solution (National diagnostics).

The amplified PCR products were purified using $1 \mu \mathrm{l}$ of ExoSAP-IT ${ }^{\circledR}$ and sequencing reactions were performed using BigDye ${ }^{\circledR}$ Terminator v3.1 according to manufacturer recommendations (Applied Biosystems) and the primers 
previously used for target DNA amplification. The sequencing reaction products were separated on a Genetic Analyzer 3130 (Applied Biosystems) equipment. DNA sequencing data obtained was analysed using Sequencing Analysis Software v.5.4 ${ }^{\circledR}$ (Applied Biosystems) and SeqScape v2.5 ${ }^{\circledR}$ (Applied Biosystems).

\section{RESULTS}

After PCR-sequencing analysis of the 99 POAG Portuguese patients it was possible to identify at least one genetic variant in MYOC gene exons or in the adjacent regions in all the patients but two. Overall, 20 different sequence variations were found, including nine coding and 11 non-coding variants (Table 1). From the coding variants four were missense alterations [c.227G>A p.(Arg76Lys), $\begin{array}{lll}\text { c.878C }>A & \text { p.(Thr293Lys), } & \text { c.1193A }>G \quad \text { p.(Lys398Arg) }\end{array}$ and c.1334C $>$ T p.(Ala445Val) (Fig. 1)] and five were synonymous variants [c.39T>G p.(Pro13Pro), c.141C>T p.(Cys47Cys), c.477A<G p.(Leu159Leu), c.975G $>A$ p.(Thr325Thr) and c.1041T>C p.(Tyr347Tyr)]. Four noncoding sequence variations were found in the promoter region (c. $-224 \mathrm{~T}>\mathrm{C}$, c. $-190 \mathrm{G}>\mathrm{T}$, c. $-126 \mathrm{~T}>\mathrm{C}$ and c. $-83 \mathrm{G}>\mathrm{A}$ ),

Table 1 - Sequence variations identified in MYOC gene of POAG patients

\begin{tabular}{|c|c|c|c|c|}
\hline \multirow{2}{*}{ Sequence variation } & \multirow{2}{*}{ Amino acid change } & \multicolumn{3}{|c|}{$\begin{array}{c}\text { Genotype } \\
(n=99)\end{array}$} \\
\hline & & $\begin{array}{c}\text { Wild type } \\
\text { homozygous }\end{array}$ & Heterozygous & $\begin{array}{c}\text { Mutant } \\
\text { homozygous }\end{array}$ \\
\hline c. $-224 T>C$ & - & 54 TT & $41 \mathrm{TC}$ & $4 \mathrm{CC}$ \\
\hline c. $-190 \mathrm{G}>\mathrm{T}$ & - & $98 \mathrm{GG}$ & $1 \mathrm{GT}$ & - \\
\hline c. $-126 \mathrm{~T}>\mathrm{C}$ & - & $94 \mathrm{TT}$ & $5 \mathrm{TC}$ & - \\
\hline c. $-83 G>A$ & - & $83 \mathrm{GG}$ & $16 \mathrm{GA}$ & - \\
\hline c. $39 T>G$ & p.(Pro13Pro) & $96 \mathrm{TT}$ & $3 \mathrm{TG}$ & - \\
\hline c. $141 \mathrm{C}>\mathrm{T}$ & p.(Cys47Cys) & $97 \mathrm{CC}$ & $2 \mathrm{CT}$ & - \\
\hline c. $227 \mathrm{G}>\mathrm{A}$ & p.(Arg76Lys) & $83 \mathrm{GG}$ & $16 \mathrm{GA}$ & - \\
\hline c. $477 A>G$ & p.(Leu159Leu) & $96 \mathrm{AA}$ & $3 \mathrm{AG}$ & - \\
\hline c. $604+50 \mathrm{G}>\mathrm{A}$ & - & $97 \mathrm{GG}$ & $2 \mathrm{GA}$ & - \\
\hline c. $605-332 \mathrm{G}>\mathrm{A}$ & - & $71 \mathrm{GG}$ & $26 \mathrm{GA}$ & $2 \mathrm{AA}$ \\
\hline c. $605-280 G>T$ & - & $16 \mathrm{GG}$ & $57 \mathrm{GT}$ & 26 TT \\
\hline c.605-210delT & - & $97 \mathrm{TT}$ & 2 Tdel & - \\
\hline c. $730+35 A>G$ & - & $45 \mathrm{AA}$ & $46 A G$ & $8 \mathrm{GG}$ \\
\hline c. $731-205 A>C$ & - & $66 \mathrm{AA}$ & $32 \mathrm{AC}$ & $1 \mathrm{CC}$ \\
\hline c. $731-73 C>T$ & - & $95 \mathrm{CC}$ & $4 \mathrm{CT}$ & - \\
\hline c. $878 \mathrm{C}>\mathrm{A}$ & p.(Thr293Lys) & $98 \mathrm{CC}$ & $1 \mathrm{CA}$ & - \\
\hline c. $975 G>A$ & p.(Thr325Thr) & $96 \mathrm{GG}$ & $3 \mathrm{GA}$ & - \\
\hline c. $1041 \mathrm{~T}>\mathrm{C}$ & p.(Tyr347Tyr) & $94 \mathrm{TT}$ & $5 \mathrm{TC}$ & - \\
\hline c. $1193 A>G$ & p.(Lys398Arg) & $97 \mathrm{AA}$ & $2 A G$ & - \\
\hline c. $1334 C>T$ & p.(Ala445Val) & $98 \mathrm{CC}$ & $1 \mathrm{CT}$ * & - \\
\hline
\end{tabular}

${ }^{*}$ Marks the individual with the variant responsible for late-onset NTG.

The nomenclature used in Table 1 for sequence variations is according to reference. ${ }^{45}$

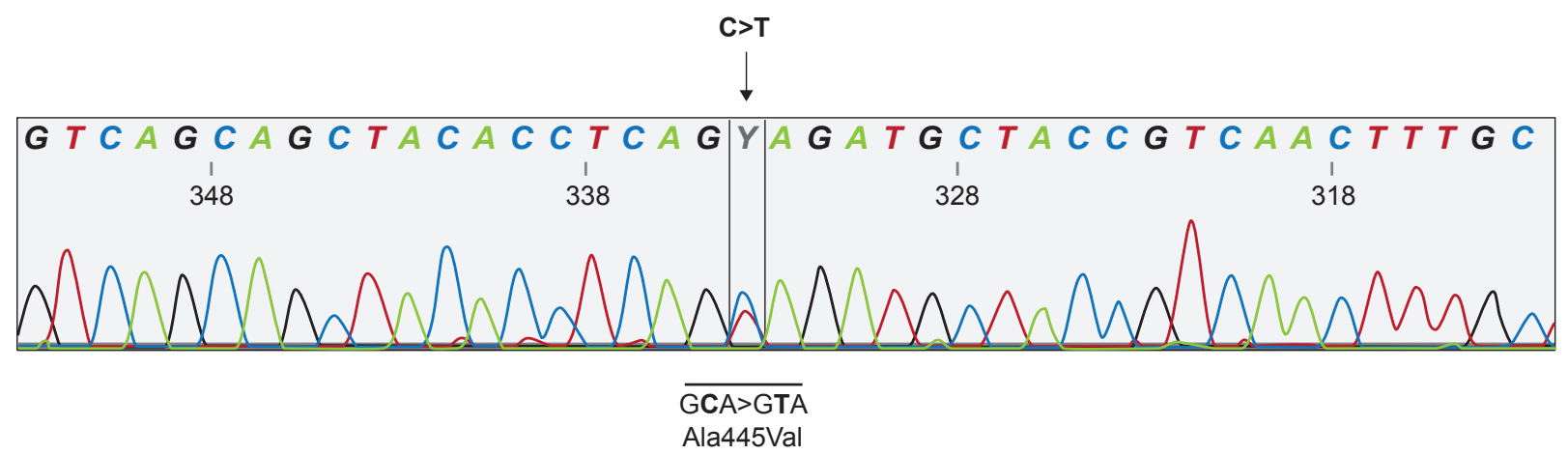

Figure 1 - Electropherogram of the genetic region surrounding variant c.1334C>T p.(Ala445Val) identified in a normal tension glaucoma patient. Heterozygous transition of a $\mathrm{C}$ to a $\mathrm{T}$ at nucleotide 1334 , changing the codon GCA to GTA and causing an Alanine to Valine amino acid substitution at position 445. The nomenclature used in Fig. 1 for sequence variation is according to reference. ${ }^{45}$ 
four were found in intron one (c.604+50G>A, c.605$332 \mathrm{G}>\mathrm{A}, \quad$ c.605-280G $>\mathrm{T}$ and c.605-210delT) and three were found in intron two (c.730+35A>G, c.731-205A>C and c.731-73C>T) (Table 1). The missense variants c.878C >A p.(Thr293Lys) and c.1334C>T p.(Ala445Val) (Fig. 1) were identified in heterozygosity in 1 patient each, the c.1193A>G p.(Lys398Arg) in two patients and variant c. $227 \mathrm{G}>\mathrm{A}$ p.(Arg76Lys) was identified in 16 patients (Table 1). It is noticeable that the promoter variant c.-83G $>A$ and the exon one missense alteration c.227G >A p.(Arg76Lys) were always found simultaneously in the same patients, even sharing the same genotype.

\section{DISCUSSION}

The sequencing analysis of the MYOC gene in 99 POAG patients allowed the identification of 20 variants including four missense alterations [c.227G>A p.(Arg76Lys), c.878C >A p.(Thr293Lys), c.1193A>G p.(Lys398Arg) and c.1334C>T p.(Ala445Val) (Fig. 1)] (Table 1). Initially, all four missense sequence variations were considered candidates to glaucoma causing disease mutations. However, after literature review, it was possible to determine that c. $227 \mathrm{G}>\mathrm{A}$ p.(Arg76Lys), c.878C>A p.(Thr293Lys) and c.1193A>G p.(Lys398Arg) variants were previously described in individuals without the glaucoma phenotype, ${ }^{21-28}$ thus likely neutral polymorphisms. Nevertheless, the variant c.1334C>T p.(Ala445Val) (Fig. 1) was previously identified only in glaucoma patients and consequently reported as a glaucoma causing mutation. 8,22,29-33

With the aim of developing a biochemical assay to distinguish different forms of myocilin protein, a cellular assay with Triton X-100 detergent was applied to determine protein solubility of mutant and normal forms of the protein, taking into consideration that misfolded myocilin mutants aggregate in the ER and are insoluble. Variant c.1193A>G p. (Lys398Arg) was one of the studied variants and the assay established its solubility, ${ }^{34}$ and consequently nonpathogenicity.

Upon crystal structure-based prediction, variant p.(Thr293Lys) is a remote surface exposed residue having wild-type-like stability, which makes it unlikely to promote misfolding of myocilin protein. ${ }^{35}$ Considering this data and the identification of c.878C>A p. (Thr293Lys) in individuals without the glaucoma phenotype, this variant is most likely a neutral polymorphism.

Variant c.1334C>T p. (Ala445Val) (Fig. 1) is located in MYOC gene exon 3 and results from an alteration at the second nucleotide of codon 445, changing an amino acid alanine to a valine. Even if it is unlikely that this amino acid change causes alterations in the protein properties since both alanine and valine are non-polar and hydrophobic amino acids, ${ }^{29}$ the strong former $\alpha$ alanine changes to a strong former $\beta$ valine may possibly cause an increased preference for a $\beta$-sheet conformation ${ }^{36}$ and a significant modification in the secondary structure of the myocilin protein. However, based on crystal structure-based prediction, p. (Ala445Val) is located on a remote surface of olfactomedin (OLF) domain ${ }^{35}$ and exhibits wild-type-like stability for OLF melting temperature, ${ }^{37}$ suggesting that it is not prone to misfolding. ${ }^{35}$ Nevertheless, using size exclusion chromatography, it was possible to determine that the p. (Ala445Val) OLF domain has a higher yield of aggregated species, allowing the identification of significant differences in the ratio of aggregate to monomer species when compared with wild type OLF domain, suggesting that p.(Ala445Val) is more similar to disease causing variants than to the wild-type.${ }^{37}$ Additionally, in the present study, the c. 1334C > T p.(Ala445Val) (Fig. 1) variant was identified in a male NTG patient with 77 yo at diagnosis and an IOP of $17 \mathrm{~mm} / \mathrm{Hg}$ in both eyes. Taking into consideration that MYOC gene mutations are mainly associated with JOAG patients with an early onset before 35 yo and very high IOP, most likely caused by severe morphological changes in $\mathrm{TM}$, our study suggests that the c.1334C>T p.(Ala445Val) variant may be responsible for a mild late onset form of glaucoma regardless of TM dysfunction and likely caused by a neurodegenerative mechanism affecting RGC, as previously proposed. ${ }^{38}$ Finally, the present study supports the glaucoma causing mutation classification for the MYOC variant c.1334C>T p.(Ala445Val) based on its association with late onset NTG and high yield of aggregated species.

Additional results obtained in the present study include four non-coding sequence variations found in the MYOC gene promoter region (c. $-224 T>C$, c. $-190 G>T$, C. $-126 \mathrm{~T}>\mathrm{C}$ and C. $-83 \mathrm{G}>\mathrm{A}$ ) (Table 1). As much as it was possible to determine from the literature review, there is no association between the MYOC gene promoter region variants and any type of glaucoma, and so it is still questionable if these variants may influence MYOC gene expression and lead to glaucoma. Also interesting for future line of research is the simultaneous identification of the promoter variant c.-83G>A and exon 1 missense alteration c.227G >A p.(Arg76Lys), even sharing the same genotype in every patient and suggesting a segregation in linkage disequilibrium as previously reported. ${ }^{32,39-42}$ If separately both are unanimously considered neutral polymorphisms for glaucoma, their impact in linkage remains elusive.

Personalized medicine using genetic information to anticipate disease onset and progression, and to implement preventive interventions for each patient is an evolving field. ${ }^{43}$ This is directly associated with the exponential drop in cost of high-throughput genome-wide genotyping platforms. ${ }^{44}$ Next generation, high-throughput DNA sequencing technology offers a powerful approach to identify causal genetic variants for many rare and common genetic disorders, including POAG. ${ }^{10}$ Genetic testing for POAG is clearly helpful in some specific situations, such as screening of family members in autosomal dominant POAG of early onset. ${ }^{44}$ Early identification of mutation carrying individuals creates the opportunity for early implementation of medical and surgical treatment alternatives for slowing down the progression or even preventing glaucoma from developing. ${ }^{43}$ But this is only possible if genetic testing is included in the diagnostic criteria for glaucoma. Recently, 
it was demonstrated that $M Y O C$ cascade genetic testing for POAG allows identification of at-risk individuals at an early stage or even before signs of glaucoma are present. ${ }^{43}$ This was only possible due to MYOC gene screening and identification of disease-causing mutations in POAG patients and further mutation screening in patients' relatives. Without genetic testing as a diagnostic criterion there will be no mutation identification, no relatives tested, no early diagnosis achieved and no preventive therapies applied. Taking into consideration the present study, gathering of DNA samples for genetic testing from relatives of the patient with variant c. $1334 \mathrm{C}>\mathrm{T}$ p.(Ala445Val) is ongoing.

\section{CONCLUSION}

This is the first study performed in a group of POAG patients from the Centre Region of Portugal contributing to the identification of one genetic variant in the MYOC gene [c.1334C>T p.(Ala445Val)], probably responsible for a mild late onset glaucoma through a neurodegenerative mechanism that is independent of TM dysfunction. These findings will enable cascade genetic testing of patient's relatives with the aim of identifying at-risk individuals and implementing therapeutic procedures to prevent the development of glaucoma. Accordingly, genetic testing should be included in the diagnostic approach for glaucoma.

\section{AUTHORS CONTRIBUTION}

FS: Substantial contribution to the conception, design of the work, acquisition analysis and interpretation of data for the work. Drafting and final approval of the version to be published.

FF: Substantial contribution to the acquisition, analysis and interpretation of data for the work. Drafting the work and revising it critically for important intellectual content. Final approval of the version to be published.

PF: Substantial contribution to the conception, acquisition and interpretation of data for the work. Revising it critically for important intellectual content. Final approval of the version to be published.

IS: Substantial contribution to the acquisition of data for the work. Revising it critically for important intellectual content. Final approval of the version to be published.

MR: Substantial contribution to the acquisition and analysis of data for the work. Revising it critically for important intellectual content. Final approval of the version to be published.

JP, JFS: Substantial contribution to the acquisition of data for the work. Revising it critically for important intellectual content. Final approval of the version to be published.

MG, HG. PP: Substantial contribution to the conception of the work. Revising it critically for important intellectual content. Final approval of the version to be published. JMP: Substantial contribution to the conception and acquisition of data for the work. Revising it critically for important intellectual content. Final approval of the version to be published.

All authors agreed to be accountable for all aspects of the work in ensuring that questions related to the accuracy or integrity of any part of the work are appropriately investigated and resolved.

\section{PROTECTION OF HUMANS AND ANIMALS}

The authors declare that the procedures were followed according to the regulations established by the Clinical Research and Ethics Committee and to the 2013 Helsinki Declaration of the World Medical Association.

\section{DATA CONFIDENTIALITY}

The authors declare having followed the protocols in use at their working center regarding patients' data publication.

\section{COMPETING INTERESTS}

The authors have declared that no competing interests exist.

\section{FUNDING SOURCES}

This work was supported by Fundação para a Ciência e Tecnologia with the Strategic Projects PEST-C/ SAU/UI3282/2011-COMPETE and PEST-C/SAU/ UI3282/2013-COMPETE. This work was also supported by Gabinete de Apoio à Investigação, Faculty of Medicine, University of Coimbra and Banco Santander Totta with the grant FSilva11.GAI2014. FS was a Post-Doc grant holder (SFRH-BPD_71016_2010) from Fundação para a Ciência e Tecnologia - Programa Operacional Potencial Humano.

\section{REFERENCES}

1. Fuse N. Genetic bases for glaucoma. Tohoku J Exp Med. 2010;22:1-10

2. Janssen SF, Gorgels TG, Ramdas WD, Klaver CC, van Duijn CM, Jansonius NM, et al. The vast complexity of primary open angle glaucoma: disease genes, risks, molecular mechanisms and pathobiology. Prog Retin Eye Res. 2013;37:31-67.

3. Fan BJ, Wiggs JL. Glaucoma: genes, phenotypes, and new directions for therapy. J Clin Invest. 2010;120:3064-72.

4. European Glaucoma Society. Chapter 2-Classification and Terminology. In: European Glaucoma Society, editors. Terminology and Guidelines for Glaucoma. $4^{\text {th }}$ ed. Savona: PubliComm; 2014. p.79-87.

5. Hong CJ, Trope GE. Glaucoma. CMAJ. 2015;187:E398-9.

6. Youngblood $\mathrm{H}$, Hauser MA, Liu Y. Update on the genetics of primary open-angle glaucoma. Exp Eye Res. 2019;188:107795.

7. Tham YC, Li X, Wong TY, Quigley HA, Aung T, Cheng CY. Global prevalence of glaucoma and projections of glaucoma burden through 2040: a systematic review and meta-analysis. Ophthalmology. 2014;121:2081-90.

8. Weisschuh N, Neumann D, Wolf C, Wissinger B, Gramer E. Prevalence of myocilin and optineurin sequence variants in German normal tension glaucoma patients. Mol Vis. 2005;11:284-7.

9. Fingert JH. Primary open-angle glaucoma genes. Eye. 2011;25:587-95

10. Liu Y, Allingham RR. Major review: molecular genetics of primary openangle glaucoma. Exp Eye Res. 2017;160:62-84.

11. Stone EM, Fingert JH, Alward WL, Nguyen TD, Polansky JR, Sunden $\mathrm{SL}$, et al. Identification of a gene that causes primary open angle glaucoma. Science. 1997;275:668-70.

12. Hulsman CA, De Jong PT, Lettink M, van Duijn C, Hofman A, Bergen AA. Myocilin mutations in a population-based sample of cases with 
open angle glaucoma: the Rotterdam Study. Graefes Arch Clin Exp Ophthalmol. 2002;240:468-74.

13. Sunden SL, Alward L, Nichols BE, Rokhlina TR, Nystuen A, Stone EM, et al. Fine mapping of the autosomal dominant juvenile open angle glaucoma (GLC1A) region and evaluation of candidate genes. Genome Res. 1996;6:862-9.

14. Kubota R, Noda S, Wang Y, Minoshima S, Asakawa S, Kudoh J, et al. A novel myosin-like protein (myocilin) expressed in the connecting cilium of the photoreceptor: molecular cloning, tissue expression, and chromosomal mapping. Genomics. 1997;41:360-9.

15. Borrás T. The effects of myocilin expression on functionally relevant trabecular meshwork genes: a mini-review. J Ocul Pharmacol Ther. 2014;30:202-12.

16. Jain A, Zode G, Kasetti RB, Ran FA, Yan W, Sharma TP, et al. CRISPRCas9-based treatment of myocilin-associated glaucoma. Proc Natl Acad Sci U S A. 2017;114:11199-204.

17. Hernandez H, Millar JC, Curry SM, Clark AF, McDowell CM. BMP and activin membrane bound inhibitor regulates the extracellular matrix in the trabecular meshwork. Invest Ophthalmol Vis Sci. 2018;59:2154-66.

18. Wang H, Li M, Zhang Z, Xue H, Chen X, Ji Y. Physiological function of myocilin and its role in the pathogenesis of glaucoma in the trabecular meshwork (Review). Int J Mol Med. 2019;43:671-81.

19. Hamanaka T, Kimura M, Sakurai T, Ishida N, Yasuda J, Nagasaki M, et al. A histologic categorization of aqueous outflow routes in familial openangle glaucoma and associations with mutations in the MYOC gene in Japanese patients. Invest Ophthalmol Vis Sci. 2017;58:2818-31.

20. Preparation and analysis of DNA. In: Ausubel FM, Brent R, Kingston RE, Moore DD, Seidman JG, Smith JA, et al, editors. In: Current protocols in molecular biology. New York: John Wiley \& Sons, Inc; 2003. p. 1-12.

21. Izumi K, Mashima $\mathrm{Y}$, Obazawa M, Ohtake $\mathrm{Y}$, Tanino $\mathrm{T}$, Miyata $\mathrm{H}$, et al. Variants of the myocilin gene in Japanese patients with normal-tension glaucoma. Ophthalmic Res. 2003;35:345-50.

22. Faucher M, Anctil JL, Rodrigue MA, Duchesne A, Bergeron D, Blondeau $P$, et al. Founder TIGR/myocilin mutations for glaucoma in the Québec population. Hum Mol Genet. 2002;11:2077-90.

23. Jia LY, Tam PO, Chiang SW, Ding N, Chen LJ, Yam GH, et al. Multiple gene polymorphisms analysis revealed a different profile of genetic polymorphisms of primary open-angle glaucoma in northern Chinese. Mol Vis. 2009;15:89-98.

24. Tanwar M, Kumar M, Dada T, Sihota R, Dada R. MYOC and FOXC1 gene analysis in primary congenital glaucoma. Mol Vis. 2010;16:19962006.

25. Whigham BT, Williams SE, Liu Y, Rautenbach RM, Carmichael TR, Wheeler J, et al. Myocilin mutations in black South Africans with POAG. Mol Vis. 2011;17:1064-9.

26. Banerjee D, Bhattacharjee A, Ponda A, Sen A, Ray K. Comprehensive analysis of myocilin variants in east Indian POAG patients. Mol Vis. 2012;18:1548-57.

27. Liu W, Liu Y, Challa P, Herndon LW, Wiggs JL, Girkin CA, et al. Low prevalence of myocilin mutations in an African American population with primary open-angle glaucoma. Mol Vis. 2012;18:2241-6.

28. Park J, Kim M, Park CK, Chae H, Lee S, Kim Y, et al. Molecular analysis of myocilin and optineurin genes in Korean primary glaucoma patients. Mol Med Rep. 2016;14:2439-48.
29. Alward WL, Fingert JH, Coote MA, Johnson AT, Lerner SF, Junqua D, et al. Clinical features associated with mutations in the chromosome 1 open-angle glaucoma gene (GLC1A). N Engl J Med 1998;338:1022-7.

30. Fingert JH, Héon E, Liebmann JM, Yamamoto T, Craig JE, Rait J, et al. Analysis of myocilin mutations in 1703 glaucoma patients from five different populations. Hum Mol Genet. 1999;8:899-905.

31. Vincent AL, Billingsley G, Buys Y, Levin AV, Priston M, Trope G, et al. Digenic inheritance of early-onset glaucoma: CYP1B1, a potential modifier gene. Am J Hum Genet. 2002;70:448-60.

32. López-Martinez F, López-Garrido MP, Sánchez-Sánchez F, CamposMollo E, Coca-Prados M, Escribano J. Role of MYOC and OPTN sequence variations in Spanish patients with primary open-angle glaucoma. Mol Vis. 2007;13:862-72.

33. Souzeau E, Burdon KP, Dubowsky A, Grist S, Usher B, Fitzgerald JT, et al. Higher prevalence of myocilin mutations in advanced glaucoma in comparison with less advanced disease in an Australasian disease registry. Ophthalmology. 2013;120:1135-43.

34. Zhou Z, Vollrath D. A cellular assay distinguishes normal and mutant TIGR/myocilin protein. Hum Mol Genet. 1999;8:2221-8.

35. Donegan RK, Hill SE, Freeman DM, Nguyen E, Orwig SD, Turnage KC et al. Structural basis for misfolding in myocilin-associated glaucoma. Hum Mol Genet. 2015;24:2111-24.

36. Chou PY, Fasman GD. Empirical predictions of protein conformation. Ann Rev Biochem. 1978;47:251-76.

37. Burns JN, Turnage KC, Walker CA, Lieberman RL. The stability of myocilin olfactomedin domain variants provides new insight into glaucoma as a protein misfolding disorder. Biochemistry. 2011;50:582433.

38. Gupta N, Yücel Y. Glaucoma as a neurodegenerative disease. Curr Opin Ophthalmol. 2007;18:110-4.

39. Mabuchi F, Yamagata Z, Kashiwagi K, Tang S, lijima H, Tsukahara S Analysis of myocilin gene mutations in Japanese patients with normal tension glaucoma and primary open-angle glaucoma. Clin Genet. 2001; $59: 263-8$

40. Lam DS, Leung YF, Chua JK, Baum L, Fan DS, Choy KW, et al. Truncations in the TIGR gene in individuals with and without primary open-angle glaucoma. Invest Ophthalmol Vis Sci. 2000;41:1386-91.

41. Pang CP, Leung YF, Fan B, Baum L, Tong WC, Lee WS, et al. TIGR/ MYOC gene sequence alterations in individuals with and without primary open-angle glaucoma. Invest Ophthalmol Vis Sci. 2002;43:3231-5.

42. Melki R, Belmouden A, Akhayat O, Brézin A, Garchon HJ. The M98K variant of the OPTINEURIN (OPTN) gene modifies initial intraocular pressure in patients with primary open-angle glaucoma. J Med Genet. 2003; $40: 842-4$

43. Souzeau E, Tram KH, Witney M, Ruddle JB, Graham SL, Healey PR, et al. Myocilin predictive genetic testing for primary open-angle glaucoma leads to early identification of at-risk individuals. Ophthalmology. 2017;124:303-9

44. Khawaja AP, Viswanathan AC. Are we ready for genetic testing for primary open-angle glaucoma? Eye. 2018;32:877-83.

45. den Dunen JT, Antonarakis SE. Mutation nomenclature extensions and suggestions to describe complex mutations: a discussion. Hum Mutat. 2000;15:7-12. 